\title{
Missionale ekklesiologie in die Afrikaanse gereformeerde kerke sedert 1990
}

\author{
Wim (WA) Dreyer \\ Universiteit van Pretoria \\ Pretoria, Suid-Afrika \\ wimdreyer@up.ac.za
}

\begin{abstract}
Missional ecclesiology in the Afrikaans reformed churches since 1990

This article argues that "missional ecclesiology" in the last decades became a new mission paradigm for churches in South Africa, especially after the demise of apartheid. After an overview of the development of a "missio Dei" theology, the article examines texts from various South African churches in which this terminology is used. The article concludes with a section which underlines the importance of missional ecclesiology in the context of the local congregation. Congregations are seen as "missional", challenged to be present in local communities as a living witness to God's love. Missional ecclesiology has its theological foundation in the "missio Dei". In missional ecclesiology, mission is understood as part of the nature of God as well as the nature of the church. Without mission there is no church. Mission is not a project, it is existential. However, there are diverse interpretations of "missio Dei", "missional ecclesiology" and "mission" itself. As a result, many congregations find it difficult to identify with missional ecclesiology and enter a process of transformation. The historical analysis presented here contributes to a better understanding of the terminology as well as the challenges facing churches in the $21^{\text {st }}$ century.
\end{abstract}

Trefwoorde

Missio Dei; missionale ekklesiologie; historiese teologie; sendinggeskiedenis; kerkgeskiedenis

\section{Inleidend}

Die Suid-Afrikaanse samelewing het sedert 11 Februarie 1990, nadat Nelson Mandela vrygelaat is, ingrypend verander (Benade \& Niemandt 2019:7). Sosio-politieke transformasie skep geleenthede, maar ook uitdagings. Dit 
geld vanselfsprekend ook vir die kerk. In tye van verandering word kritiese vrae gevra, onder andere oor die identiteit en relevansie van die kerk in 'n veranderende samelewing. Die wese en die roeping van die kerk, asook die uitdagings waarmee die kerk in die 21ste eeu gekonfronteer word, verskyn gereeld op die agenda van kerklike vergaderings.

Daar is baie uitdagings waarmee kerke in Suid-Afrika worstel, onder andere die daling van lidmaatgetalle. Die drie Afrikaanse susterskerke ${ }^{1}$ se dooplidmate het die afgelope dekades met meer as 50\% verminder, hoofsaaklik as gevolg van 'n besonder lae geboortesyfer asook groot getalle jongmense wat emigreer. Daarbenewens het groeiende sekularisasie die daling in lidmaatgetalle versnel. Volgens die WIN-Gallup meningsopname het godsdienstige affiliasie in Suid-Afrika van 2005 tot 2012 (in sewe jaar) afgeneem van $83 \%$ tot $64 \%$, 'n afname van bykans $20 \%$ (aangehaal in Benade \& Niemandt 2019:7; sien ook Dreyer 2016:146-154).

Een van die moeilikste uitdagings waarvoor kerke te staan gekom het, is om verantwoordelik en geloofwaardig die evangelie na buite te verkondig. Nie net is die praktyk uitdagend nie, maar die teologiese begronding van die kerk se sendingopdrag het problematies geword. "Missionale ekklesiologie" het sedert 1990 'n gonswoord onder Afrikaanse teoloë geword. Dit het kerke gehelp om tot 'n nuwe verstaan van kerkwees en sending te kom, hoewel dit dikwels met weerstand begroet word. Tog is die voorlopige aanduidings dat dit daartoe bydra dat kerke en gemeentes met nuwe energie, te midde van baie groot uitdagings, voortgaan met die verkondiging van die evangelie.

Missionale ekklesiologie word teologies in die missio Dei begrond. Dit beteken dat sending nie net een van die kerk se projekte is nie. Sending het as uitgangspunt die wese van God, wat in liefde gekies het om vir die mens God te wees en sy Seun, sy Woord, sy Gees en sy kerk na die wêreld stuur. In missionale ekklesiologie word die plaaslike gemeente die "sendeling".

1 In die omgangstaal verwys "Afrikaanse susterskerke" na die Nederduitse Gereformeerde Kerk (NGK), Nederduitsch Hervormde Kerk van Afrika (NHKA) en die Gereformeerde Kerke in Suid-Afrika (GKSA) wat sedert 1824, toe die Eerste Algemene Kerkvergadering in Kaapstad sitting geneem het, organies vanuit die Kaapse kerk gegroei het. Die susterskerke het oor die algemeen Afrikaans as voertaal en staan histories in 'n bepaalde verband met mekaar. In hierdie bydrae word dokumente van die NGK, NHKA, GKSA asook die VGKSA op die tafel geplaas. 
Gemeentes word uitgedaag om daar waar hulle is, só te leef dat dit getuig van God se liefde.

Hierdie artikel lê op die terrein van die Historiese Teologie. Die vraag word aangespreek hoe die Afrikaanse gereformeerde kerke vanuit 'n histories-teologiese perspektief in die afgelope drie dekades nagedink het oor sending, missio Dei en missionale ekklesiologie. Verder word die vraag ook aangeroer of die kerke 'n wesenlike bydrae gelewer het in die huidige diskoers oor missionale ekklesiologie, en of dit alles eweneens 'n bydrae lewer tot sinvolle vernuwing in die gees van ecclesia semper reformanda.

\section{Kan ons nog van sending praat?}

Sendinggeskiedenis is ten nouste verweef met kerkgeskiedenis en teologiegeskiedenis (Saayman 2003:195). Sending, kerk en teologie is onlosmaaklik aan mekaar verbind.

Sedert prof. J. Du Plessis in 1911 sy bekende Christian Missions in South Africa (Du Plessis 1911 [Heruitgawe 1965]) gepubliseer het, was sendinggeskiedenis dikwels die onderwerp van navorsing. Talle artikels, boeke en doktorale verhandelings gee 'n duidelik beeld van vroeëre sendingwerk. Akademici vanuit die susterskerke wat hieraan meegedoen het sluit in JS de Klerk, WJ Van der Merwe, CWH Boshoff, PS Dreyer, PJS de Klerk, PG Geertsema, JJ Kritzinger, W Saayman, IWC van Wyk, D Bosch en ander. Bekende skrywers soos Karel Schoeman en Elsa Joubert het in verskeie publikasies aandag gegee aan die lewe en werk van die vroeë sendelinge.

Sending in Suid-Afrika het deur verskillende fases gegaan. Saayman (2007) onderskei vier fases waardeur sending in Suid-Afrika beweeg het. Sending is aanvanklik deur sendinggenootskappe (byvoorbeeld die Morawiese, Londense, Berlynse, Amerikaanse, Suid-Afrikaanse en Hervormde Sendinggenootskappe) bedryf, terwyl kerke bestaande lidmate bedien het. Sending is tweedens gesien as "opheffingswerk" wat deur mense van Europese afkoms onder inheemse bevolkingsgroepe gedoen word. Dit het in Suid-Afrika tot die wydlopende verskynsel van "wit" en "swart" kerke gelei. Kritzinger (2011:112) noem dit die "klassieke sendingmodel”. In 'n "derde fase" staan sending dikwels in verband met kolonialisme, kultuur- 
imperialisme, patriargie en rassisme. In Suid-A frika is daar kerke (veral die sogenaamde "dogterkerke" van die Afrikaanse kerke) wat uiters sensitief vir die begrip "sending" is. Daar is goeie redes vir hierdie sensitiwiteit, wat histories aantoonbaar is.

Saayman (2007:100) is van mening dat 'n "vierde sendinggolf" vanaf 1990 aan die gang gekom het. Ek meen egter dat om die "vierde golf" onder die opskrif To the ends of the earth (sien Benade \& Niemandt 2019:5) te plaas, is oordrewe. Afrikaanse kerke se internasionale sendingprojekte is maar uiters beperk. Dit is opmerklik dat die ywer en entoesiasme vir sendingwerk die laaste drie dekades getaan het. Kritzinger (2011) kan selfs praat van die "einde van sending". Aan die begin van die negentigerjare skryf David Bosch ([1991] 2006:3-5) dat daar 'n baie gebrekkige sendingbewussyn sigbaar is. Sending het 'n kontensieuse onderwerp geword (Richebächer 2003:588), in so 'n mate dat daar selfs sprake is van 'n "sendingkrisis".

Die "sendingkrisis" dwing teoloë om deurlopend na te dink oor die roeping van die kerk en hoe dit moontlik sou wees om in gehoorsaamheid aan Christus die evangelie uit te dra. Die resultaat was 'n groot diversifikasie in teologiese nadenke oor sending, wat Bosch 'n "pluriverse of missiology" noem (Bosch [1991] 2006:7). In 142 bladsye (hoofstuk 12 van Transforming Mission) gee Bosch 'n uitgebreide historiese oorsig van 'n "emerging ecumenical missionary paradigm" wat in die periode na die Tweede Wêreldoorlog na vore gekom het (Bosch [1991] 2006:368-510). In sy oorsig onderskei Bosch die volgende benaderings tot sending:

- Mission as church-with-others

- Mission as missio Dei

- Mission as mediating salvation

- Mission as the quest for justice

- Mission as evangelism

- Mission as contextualisation

- Mission as liberation

- Mission as enculturation

- Mission as common witness

- Mission as ministry by the whole people of God 
- Mission as witness to other faiths

- Mission as theology

- Mission as action in hope

Hierdie diversiteit in die verstaan van die kerk se sendingopdrag maak dit moeilik om van "sending" te praat, asof daar net een definisie is en almal eenstemmig daaroor is. Die diversiteit word veroorsaak deur verskille in konteks en teologie; uiteenlopende analises en formulerings van verskillende sendingkonferensies; die invloed van die ekumeniese beweging en 'n soeke na politieke en ekonomiese geregtigheid na die Tweede Wêreldoorlog.

Ten spyte van die bogenoemde diversifikasie is daar tog internasionaal breë konsensus oor missio Dei as teologiese fundering van sending (sien Benade 2019:153-193). Met die missio Dei as uitgangspunt het "missionale ekklesiologie" vir baie teoloë en kerke die raamwerk gebied om oor sending asook die wese en roeping van die kerk na te dink. Dit is ook toenemend verpraktiseer in die alledaagse bestaan van die kerk.

\section{Missio Dei}

Missio Dei is een van die belangrikste teologiese denkbeelde wat in die loop van die 20ste eeu na vore gekom het. Dit het tot 'n nuwe verstaan van kerkwees en die kerk se sendingopdrag gelei. Dit het 'n fundamentele invloed op die ekumeniese beweging en -teologie uitgeoefen. Dit het gelei tot 'n herdefiniëring van sosiale geregtigheid en die kerk se plek in die wêreld. Dit het baie kerke gehelp om tot 'n herdefiniëring van identiteit en roeping te kom.

Bosch ([1991] 2006:390) beskryf die invloed en omvang van die missio Deidenke soos volg: "Since Willingen, the understanding of mission as missio Dei has been embraced by virtually all Christian persuasions - first by conciliar Protestantism, but subsequently also by other ecclesial groupings, such as the Eastern Orthodox and many evangelicals. It was also endorsed in Catholic mission theology, notably in some of the documents of the Second Vatican Council”.

Ten spyte hiervan kan die begrip missio Dei problematies wees. Buys (2020:1) haal verskeie outeurs aan, wat daarop dui dat nie almal eenstemmig is oor die belang van missio Dei nie, en dat dit selfs 'n wesenlike afwyking 
van die reformatoriese teologie impliseer. Missio Dei word in verskillende kontekste uiteenlopend verstaan en verwoord. Hieroor sê Flett (2014:70): "Missio Dei lacks theological development ... and has proven susceptible to the political or social Zeitgeist." Dit blyk ook uit referate wat in 2002 tydens die 50-jarige herdenking van die Willingen Sendingkonferensie gelewer is. Dié referate is gepubliseer in die International Review of Mission (Vol. 92, no. 367) wat deur die Wêreldraad van Kerke uitgegee is. Tydens die konferensie het verskeie referente daarop gewys hoe verskillend die missio Dei verstaan en gebruik word (sien byvoorbeeld Richebächer 2003; Engelsviken 2003). Engelsviken (2003:491) onderskei twee benaderings tot die missio Dei:

One draws especially on John 20:21, which one could call the "classical" way to refer to missio Dei, where God's mission is primarily carried out through the church. The other understanding is where God is seen as active in the secular political and social events of the world and where it is the role of the church to discern what God is doing in the world, and then participate in it. The latter understanding which, as we have seen was dominant in the WCC in the 1960s, is still a quite common understanding in ecumenical missiology.

Daarbenewens het die "evangelicals" 'n eie benadering, met besondere klem op die rol van die Seun en die Heilige Gees in bekering en verlossing. Die missio Dei is volgens hierdie opvatting die handelinge van God wat deur die Seun en die Gees mense tot bekering en verlossing bring. Dit is dus 'n soteriologiese verstaan van missio Dei.

Teoloë soos John Hick, Wilfred Smith, Paul Knitter en ander meen weer dat missio Dei teosentries verstaan moet word, wat beteken dat God deur alle godsdienste in alle mense werksaam is, in wese 'n universalistiese verstaan van die missio Dei (Engelsviken 2003:493).

Sommige teoloë is van mening dat missio Dei 'n niksseggende sambreelterm geword het waaronder enigiets wat ongeveer met sending of die kerk te doen het, tuisgebring word. Vanuit die praktyk word dit somtyds as eindelose teorievorming gesien, sonder dat dit tot konkrete aksie lei. Ander meen weer dat missio Dei apatie ten opsigte van sending veroorsaak, omdat 
alles sending word en gevolglik niks meer sending is nie. Die vraag is dus: Wat verstaan ons onder missio Dei?

Met die vergadering van die International Mission Conference te Willingen (1952) het die missio Dei-denke alreeds wyd invloed uitgeoefen (Flett 2010:11). Tydens die konferensie word onomwonde verklaar: "The missionary obligation of which we are a part has its source in the Triune God Himself" (Bosch [1991] 2006:390). Na afloop van die Willingen Konferensie het Hartenstein (kort voor sy dood op 1 Oktober 1952) die besluite van die konferensie vir die Duitssprekende wêreld versorg. Engelsviken (2003:482) gee die besluite soos volg weer:

Mission is not just the conversion of the individual, nor just obedience to the word of the Lord, nor just the obligation to gather the church. It is the taking part in the sending of the Son, the missio Dei, with the holistic aim of establishing Christ"s rule over all redeemed creation.

Volgens Bosch het hierdie Trinitariese verstaan van die missio Dei die fundering van sending verskuif, van ekklesiologie en soteriologie na die wese en handelinge van God Drie-enig. Engelsviken (2003:481) som die verskuiwing by Willingen soos volg op:

... we also want to remember the dramatic developments in missiology during the second half of the last century that in many ways began in Willingen. The development that found its most extreme form in the 1960s and early 70s involved a change from a more anthropocentric understanding of mission to a more theocentric, and from a more ecclesiocentric perspective to a more cosmocentric. In the latter perspective, the world, both in its sociopolitical and religious dimensions, is at the centre of attention.

Die Amerikaanse verslag (aangehaal in Joseph 2019:44) formuleer die Willingen Konferensie se verstaan van die missio Dei soos volg:

The missionary movement, of which we are a part, has its source in the Triune God Himself. Out of the depths of His love for us, the Father has sent forth His own beloved Son to reconcile all things to Himself, that we and all men might, through the Spirit, be made one in Him with the Father in that perfect love which is the very nature 
of God ... We who have been chosen in Christ, are by these very facts committed to full participation in His redeeming mission. There is no participation in Christ without participation in His mission to the world. That by which the Church receives its existence is that by which it is also given its world-mission ... The sending of the Son to reconcile the universe through the power of the Spirit is the foundation and purpose of mission. The missio ecclesiae comes from the missio Dei alone. Thus, mission is placed within the broadest imaginable framework of salvation history and God's plan for salvation.

Een van die invloedrykste Suid-Afrikaanse teoloë van die 20ste eeu, was David Bosch (1929-1992). Bosch se bydrae tot sendingwetenskap en die sendinggeskiedenis is omvangryk en word wêreldwyd hoog aangeslaan (Kärkkäinen 2002:14). Sy Transforming Mission word in byna elke teologiese fakulteit en seminarie in die wêreld as voorgeskrewe handboek in sendingwetenskap gebruik. Daar verskyn bykans jaarliks 'n nuwe uitgawe ${ }^{2}$. Daar is baie min sendingpublikasies (internasionaal en in Suid-Afrika) wat nie na Bosch en Transforming Mission verwys nie. Transforming Mission is al beskryf as een van die belangrikste teologiese boeke van die 20ste eeu. In die voorwoord van die jubileumuitgawe van Transforming Mission beskryf Gerald Anderson Bosch as die "preeminent Protestant missiologist, his contribution and influence in mission studies globally was immense" (Anderson 2006:xiii). Vanuit Rooms Katolieke geledere skryf Bevans \& Schroeder (2005:69) "after the twentieth century, any missiology can be done only as a footnote to the work of David Bosch."

In die periode na 1990 het Bosch se invloed ook in Suid-Afrika toegeneem. Benade \& Niemandt (2019:7-8) formuleer dit soos volg: "Around the late 1990s, the work of David Bosch was becoming popular in academic circles in South Africa. His emphasis on the missionary nature of the church, the Trinity, the missio Dei, was starting to influence the theology in the DRC." David Bosch se teologie het daartoe bygedra dat die missio Dei-denke en missionale ekklesiologie in Suid-Afrikaanse kerke inslag gevind het. Bosch ([1991] 2006:10) definieer missio Dei soos volg:

2 Die uitgawe wat in hierdie bydrae gebruik word (Bosch [1991] 2006) is alreeds die 22ste uitgawe wat oor 'n periode van 25 jaar verskyn het. 
[Missio Dei is] God's self-revelation as the One who loves the world, God's involvement in and with the world, the nature and activity of God, which embraces both the church and the world, and in which the church is privileged to participate. Missio Dei enunciates the good news that God is a God-for-people.

Bosch onderskei tussen "mission" (enkelvoud) en "missions" (meervoud). Die eerste dui op God se handelinge met die wêreld (actio Dei - Barth); die tweede op die handelinge van die kerk in die uitdra van die evangelie. In hierdie benadering staan die Triniteit sentraal: Die Vader stuur die Seun; die Vader en die Seun stuur die Heilige Gees; die drie-enige God stuur die kerk (Benade 2019:165). In hierdie Trinitariese verstaan van die missio Dei volg Bosch op die voetspoor van Karl Barth en Karl Rahner wat Augustinus se Triniteitsleer vir die kerklike praktyk geaktualiseer het (Benade 2019:165).

Verder, soos in die teologie van Hartenstein en Vicedom (sien Hartenstein 1928; 1933; 1939; sien ook Vicedom 1958; 1975), staan die koninkryk van God sentraal in Bosch se verstaan van die missio Dei. Die kerk is nie die koninkryk van God nie, maar'n teken van die koninkryk van God. Daarom gaan sending om baie meer as die indiwidu se bekering en persoonlike geloof; dit gaan ook om geregtigheid in mense se alledaagse bestaan. Die doel van sending is nie die kerk nie, maar die koninkryk van God. Die kerk en koninkryk staan nie teenoor mekaar nie, maar die kerk moet reeds iets van God se koninkryk in die teenswoordige vertoon (sien Benade 2019:168-170).

Ten slotte: Missio Dei is nie maar net 'n sendingteorie nie, maar ten diepste 'n geloofsbelydenis - 'n belydenis dat God bestaan en handelend in die lewe van mense teenwoordig is. Die gesprek oor die Triniteit; die wese van God as God-vir-mense; die koninkryk van God; die kerk as deelnemer en gestuurde en dissipelskap verdiep ons insig ten opsigte van kerkwees in die 21ste eeu. Dié oortuiging het na 1990 die Afrikaanse kerke grondig beïnvloed in terme van die kerk se roeping in die wêreld. Dit kom duidelik in die onderskeie kerke se sinodale besluite na vore. 


\section{Besluite van sinodale vergaderings na $\mathbf{1 9 9 0}$}

Ruimte ontbreek om die omvangryke studiestukke en navorsing oor missionale ekklesiologie wat sedert 1990 in die verskillende kerke in omloop was, volledig te behandel. Breedvoerige gesprek en konsultasie het plaasgevind voordat besluite geneem kon word (sien in die verband Benade \& Niemandt 2019; Dreyer 2013).

Vervolgens word enkele sinodale besluite redelik volledig aangehaal, nie net om die verskillende kerke se dokumente in een dokument beskikbaar te stel nie maar ook om daarmee aan te toon hoe die Afrikaanse kerke in die resente tyd op 'n vernuwende wyse, en in lyn met die missio Dei, oor kerkwees en sending nagedink het.

\subsection{Nederduitse Gereformeerde Kerk (NGK)}

Die afgelope 20 jaar is daar op sinodale vergaderings van die NG Kerk indringend oor die wese en roeping van die kerk besin. Die amptelike sendingbeleid wat in 1998 aanvaar is, het die missio Dei as vertrekpunt gehad (Benade \& Niemandt 2019:8).

Verskeie amptelike dokumente van die NG Kerk (Roepingsverklaring 2002; Seisoen van Luister 2005; Roepingsverklaring 2007; Groei oor Grense 2009) het beklemtoon dat die plaaslike gemeente die missio Dei beliggaam en dat elke lidmaat 'n verantwoordelikheid het om die evangelie uit te dra. Die kerk moet afstand doen van mag en diensbaar word in die wêreld.

Die Algemene Sinode van die NG Kerk het in 2013 voortgegaan met die ontwikkeling van 'n missionale ekklesiologie vir die NG Kerk. Dit is verwoord in die Raamwerkdokument oor die missionale aard en roeping van die NG Kerk. Die omvangryke dokument is beïnvloed deur die WRKdokument Together towards life: Mission and evangelism in changing landscapes (Benade en Niemandt 2019:8).

Die volgende gedeelte is 'n kort uittreksel uit 'n verslag wat deur proff. Nelus Niemandt en Piet Meiring (2007) opgestel is en voor die Algemene Sinode gedien het. Die verslag toon duidelik hoe die NGK se kerkbegrip en verstaan van sending in terme van 'n missionale ekklesiologie tot uitdrukking kom:

Die kerk en die kerk se sending word vanuit die wese van God self verstaan. Sending is nie een of ander menslike prestasie nie, maar is 
'n geskenk van God self. Ons leer God in die Bybel ken as 'n sturende God. Daarom word daar van die missio Dei gepraat. Die lewe van God is 'n proses van gestuurdheid: die Vader het die wêreld so lief dat Hy sy enigste Seun stuur om nuwe lewe te bring. Die Seun stuur die Heilige Gees. Vader, Seun en Heilige Gees stuur die kerk in die wêreld in (missio ecclesiae).

God, leer die Skrif ons, neem self die eerste inisiatief: Die Vader het in liefde na die mensdom uitgereik en sy Seun gestuur. Die Seun het as eerste Gestuurde na die aarde gekom om God se heilsplan bekend te maak en in werking te stel. Toe Jesus se werk voltooi is, het die Vader en die Seun die Heilige Gees na die wêreld gestuur om God se heilswerk te bevestig.

Die drie-enige God is dus die teenoorgestelde van 'n gemeenskap wat ter wille van sigself bestaan - van ewigheid af is God 'n heilige gemeenskap wat na buite gerig is. Daarom is Christelike sending die verkondiging van die koninkryk van die Vader om lewe in die liefde van die Seun met almal te deel en om getuies van die Gees te wees. So het die Algemene Sinode (2007) dit ook gesien. In navolging van God is die kerk na buite gerig: "Die roeping van die kerk kan as gestuurdes van God omskryf word. Die kerk behoort in wese altyd op die wêreld gerig te wees en op pad na die wêreld te wees."

Hoe pas die kerk by die missio Dei in? Waartoe bestaan die kerk en waartoe is sy gestuur? Die kerk is eerstens die resultaat van God se missie, en dan daarna deelnemer daaraan.

Deur Christus is die kerk egter verbind aan die drie-enige God en aan sy werk op aarde. Ons glo dat die kerk aan Hom alleen behoort en in verbondenheid met Hom bestaan. Die kerk is die volk van God, die liggaam van Christus en die tempel van die Gees. Alles wat ons is en doen - ons identiteit, ons missie en ons bediening - word deur hierdie verhouding bepaal. Dat alles wat die kerk is en doen gedefinieer behoort te word deur sy verhouding met die lewende God is die eerste en mees basiese beginsel van kerkwees. In die Roepingsverklaring van die NG Kerk (2007) word dit treffend verwoord: "Ons besef opnuut God roep die NG Kerk deur sy Woord en Gees om aan Hom te behoort. Christus, die Hoof van die kerk, stuur ons om ons roeping te gehoorsaam en ons daaraan toe te wy om met 
'n leerbare gees die wil van God deur sy Woord te leer ken en uit te leef in die uitdagende en komplekse wêreld waarin ons lewe.

Sending is die manier waarop die kerk lewe. Die kerk is geroep om 'n "teken" van God se koninkryk te wees, om aan die mensdom 'n voorsmaak van God se genesende heerskappy te bied. As kerk, as gestuurde gemeentes, word ons bymekaargemaak, gevorm en gestuur om die boodskap van God se liefde verder te dra.

Die formulering van die kerk se wese en roeping (nature and mission) in terme van missio Dei het verreikende gevolge. Dit beteken dat die ou verstaan van sending, waar kerke van Europese afkoms sending doen onder onbekeerde heidene in Afrika, van die tafel gevee word. In daardie sin is dit 'n postkoloniale verstaan van die kerk se roeping, getuienis en bestaan in die wêreld. Dit verteenwoordig 'n paradigmaskuif, weg van 'n ou rasse- en kolonialistiese ekklesiologie na 'n ekklesiologie wat erns maak met die handelinge van God met die wêreld en alle mense, ongeag afkoms.

\subsection{Nederduitsch Hervormde Kerk van Afrika (NHKA)}

Die NHKA het sedert 1990 breedvoerige gesprek gevoer oor 'n nuwe verstaan van kerkwees (sien Dreyer 2011 vir 'n historiese oorsig). Talle besluite is geneem, memoranda het by Algemene Kerkvergaderings gedien. In 2006 het die Kommissie van die Algemene Kerkvergadering 'n gesprek georganiseer, waaraan 'n groot getal lidmate en predikante deelgeneem het. Die proses Nasionale Colloquium oor Kerkwees in die 21ste Eeu het verreikende gevolge gehad en gelei tot besluite oor apartheid, volkskerk, ekumene maar veral missionale kerkwees. 'n Belangrike besluit is tydens die Algemene Kerkvergadering van 2007 geneem, dat die Kerkorde van die NHKA herskryf moet word op grond van 'n missionale ekklesiologie. Die proses het nege jaar geneem om af te handel. In Ordereël 7 (NHKA 2016b:77) word dit soos volg geformuleer:

\subsection{Missionale bediening}

7.1.1 Gehoorsaam aan die opdrag van Christus, leef gemeentes missionaal, getuig met woord en daad van God se liefde en leer mense hoe om Jesus Christus te volg. 
In 2016 het die Algemene Kerkvergadering 'n rigtinggewende besluit oor kerkwees in die toekoms geneem, waarin die invloed van die missio Dei-denke en missionale ekklesiologie duidelik sigbaar is (NHKA 2016a:1-2). Dit is heel aan die begin van die vergadering as eerste beskrywingspunt gestel, om die gang van die vergadering en verdere besluitneming te fasiliteer. Let onder andere op die Trinitariese, eskatologiese en ekklesiologiese uitgangspunte wat tipies is aan die missio Dei-denke:

\section{Beskrywingspunt 1: Kerkwees in die toekoms}

1. Die 71ste Algemene Kerkvergadering van die Nederduitsch Hervormde Kerk van Afrika is daarvan oortuig dat die uitdagings van ons tyd nie bepalend vir die wese van die Kerk kan wees nie. Die wese van die kerk word bepaal deur God Drie-enig.

2. Die Hervormde Kerk leef tussen die koms en die wederkoms van die Here. Die kerk is soos 'n bruid wat wag op haar Bruidegom, 'n eskatologiese gemeenskap op reis na die nuwe Jerusalem. Hierdie wêreld is nie die finale werklikheid nie. Daarom verkondig die Hervormde Kerk aan die wêreld dat net Jesus Christus hoop vir die toekoms bied.

3. Die Hervormde Kerk wil kerk van die Woord wees. Die Woord van God is die enigste bron vir die verkondiging van die evangelie. Ons bely in gehoorsaamheid aan die Woord ons geloof in God Drie-enig: Vader, Seun en Heilige Gees. Op grond van die Woord verstaan ons die Hervormde Kerk as deel van die volk van God, die huisgesin van die Vader, die liggaam van Christus en die tempel van die Heilige Gees.

4. Die Hervormde Kerk is 'n sigbare gestalte van die een, heilige, algemene en apostoliese kerk. Deur die genade van God is ons in Christus ingelyf, en het ons die doop as sigbare teken daarvan ontvang. Daarom leef die Hervormde Kerk in gemeenskap met God, in gemeenskap met mekaar en met alle gelowiges wat bely dat Jesus Christus die enigste Here is. Elke keer wanneer ons aan die Nagmaaltafel aansit, bely ons opnuut ons geloof, en word die onderlinge gemeenskap en die eenheid in Christus sigbaar. 
5. Ons glo dat God Drie-enig die Hervormde Kerk in die wêreld wil gebruik. Omdat die evangelie ons in beweging bring, wil ons, gehoorsaam aan Christus se opdrag in Matteus 28, dit ook met ander deel. Daarom wil die Hervormde Kerk missionaal leef. Dit doen elke gemeente deur die geloof in Jesus Christus met Woord en lied te vier, aan mense diensbaar te wees en te getuig van God se genade. Die manier hoe gemeentes dit doen is om in alle eenvoud en nederigheid in die voetspore van Christus te volg en diensbaar te wees soos Hy ons leer. Ons is diep bewus daarvan dat ons onsself daagliks moet verloën, ons kruis moet opneem en dat ons heil nie te vind is in wêreldse mag of indrukwekkende strukture nie, maar in Christus self. Daarom word elke gemeente en lidmaat van die Hervormde Kerk opgeroep om in geloof en vertroue te luister na die roepstem van die Goeie Herder, en Hom te volg waar Hy ons ook al lei.

6. Die eenheid van die kerk is die werk van die één God en één Gees. Die eenheid van die kerk, en nie die verskeidenheid nie, is 'n gawe en 'n opdrag aan die kerk. Tog erken ons ook die verskeidenheid en diversiteit in die kerk van Christus. Ons lees in Romeine 12 en 1 Korintiërs 12 van die verskillende gawes van die Gees en verskeidenheid onder gelowiges. Diversiteit is nie 'n bedreiging vir die kerk nie en die verskillende stemme wat in lof tot God opgaan, is 'n simfonie tot eer van God. Skakeringe in spiritualiteit word daarom gerespekteer. Tog kan die Hervormde Kerk nooit met die verskeidenheid volstaan en die eenheid verbygaan nie. Versoenende eenheid bly die Kerk se opdrag vir die hede en die toekoms. Die Hervormde Kerk handhaaf die eenheid van die kerk, diep bewus daarvan dat ons in 'n gebroke werklikheid kerk moet wees.

Die ekklesiologie wat in dié besluit van die Algemene Kerkvergadering verwoord word, verteenwoordig 'n intensionele breuk met die volkskerklike ekklesiologie soos dit histories ontwikkel het. Missionale ekklesiologie het die moontlikheid gebied om op 'n nuwe en teologies-verantwoorde wyse oor die kerk te dink. Die verandering het al duideliker na vore gekom in die gebruik van die slagspreuk "kerkwees in die voetspore van Christus", die embleem van die voetewassing en die inrigting van die agenda van die afgelope Algemene Kerkvergaderings aan die hand van vier afdelings, te 
wete gemeenskap (koinonia), viering (leitourgia), diensbaarheid (diakonia) en getuienis (marturia). Daar is ook in 2010 'n Sentrum vir Missionale Bediening in die lewe geroep met die opdrag om gemeentes op die pad van missionale kerkwees te begelei.

\subsection{Verenigende Gereformeerde Kerk (VGKSA)}

Tydens 'n gesamentlike konferensie tussen die NG Kerk en die NG Sendingkerk (die latere VGKSA) wat in April 1986 in Bellville plaasgevind het, is daar reeds 'n "working definition" van sending gegee, waarin missio Dei en missionale ekklesiologie as vertrekpunt geneem word. Dit blyk uit die volgende aanhaling?

- Mission is according to the Bible God's mission; as Father, Son and Holy Spirit God is the Subject of mission.

- In mission God has the salvation (shalom) of the world in mind and He will accomplish it through the realisation of his Kingdom. Mission gives expression to God's concern and plan of redemption for the world in all its dimensions.

- For this purpose, the Father sent his Son to the world to gather his church and send it into the world in the power of the Holy Spirit.

- The very essence of the church as the body of Christ is to live a missional life in the world. The entire church and every believer in particular stand under God's commission, in dependence on and in obedience to the Holy Spirit."

Gesien vanuit 'n historiese perspektief, was hierdie definisie 'n belangrike draaipunt weg van die tradisionele verstaan van sending en is dit opvallend dat missio Dei en die konsep van missionale kerkwees reeds geartikuleer word, selfs voor die publikasie van David Bosch se publikasie van Transforming Mission en Guder se publikasies oor missionale kerkwees. Bosch se invloed moet egter veronderstel word.

In 2007 het die Algemene Sinode van die NG Kerk die inisiatief geneem om die ander kerke in die NG Kerk-familie te betrek in 'n proses van nadenke, beplanning en aksie ten opsigte van diensbaarheid en die uitdra

3 Sien aanhaling in Our calling to service and witness in unity. A theological basis for the DRC family's missional ministries, p.24. 
van die evangelie in die wêreld. Ander kerke en sending organisasies sou ook deel vorm van die projek. 'n Taakspan is aangewys wat 'n voorlopige beleidsraamwerk moes opstel. Die taakspan het akademici soos proff. Johan Botha, Klippies Kritzinger, Nico Botha, Attie van Niekerk en Piet Meiring geraadpleeg, asook verskeie predikante van verskillende kerke. Die beleidsraamwerk is bekendgestel met die titel Our calling to service and witness in unity. A theological basis for the DRC family's missional ministries. Die doel van die dokument was om die teologiese onderbou vir missionale bediening asook vir die konsep "service and witness in unity" (bl.9) te verskaf. Opvallend is hoe dikwels die dokument na die werk van Bosch en Guder verwys en hoe invloedryk die twee teoloë se denke op die ontwikkeling van 'n nuwe benadering tot sending in die NG Kerk-familie was.

Die dokument bevat onder andere 'n gesamentlike verklaring (bl. 11-13) waarin die teologiese uitgangspunte duidelik geartikuleer word:

\section{The mission of the Triune God}

1.1 The Church's calling to service and witness in unity flows from the being of the Triune God. The very life of God is characterised by covenant, reaching out, self-communication, mutuality, relation and unity - God is love (Deus caritas est), seeking communion. The acts of God, as revealed in creation, scripture and throughout history, are characterised by God's love for the world, inviting people to enter a new world, a Trinitarian space, where the God of communion extends hospitality and care and makes all things new (Missio Trinitatis Dei).

1.2 The mission of service and witness expresses God's love and compassion to bring salvation in all its dimensions (shalom) to all people and the whole of creation. (Ex 3:7-8, Ex 19:5-6, Ex 34: 6-9, Ps 146: 6-10, Lk 4:18-19, Jn 17:11, 17, 20-23, Mt 28:18-20, Jn 20:21-22, Acts 1:8, 1 Jn 4: 7-21, Eph 4:17, Rev 21:5).

\section{The mission of Christ}


2.1 The Father has sent the Son into the world to gather God's church from all the nations and to send us into the world in the power of the Holy Spirit (Jn 3:16-17, Jn 20:21-22).

2.2 The salvation that Christ achieved is all-encompassing. It includes the forgiveness of our sins, our liberation on all levels of life as well as the liberation of creation. God's salvation of the world is realised in that He builds his Kingdom here and now. This Kingdom will, however, only come to full realisation with Christ's second coming, when all things will be new, and all nations and people will glorify God (Ezek 47:12 and Rev 22:2, Rev 21:1-5).

\section{In the power of the Holy Spirit the Church is sent}

3.1 As the body of Christ our Lord and Saviour, the essence of the church is to participate in God's mission in this world (missio ecclesiae). The local congregation as primary agent of God's mission, but also the church as a whole and all its members, are under the commission of God. Dependent on and guided by the Holy Spirit, we are called as prophets, priests and kings, to:

3.1.1 live in the presence of God (coram Deo), obedient to the word of God,

3.1.2 a ministry of worshipping God and praying for the world (leitourgia),

3.1.3 minister the Gospel of God's salvation to all people through word (kerugma), deed (diaconia) and in a relationship of love and unity (koinonia),

3.1.4 seek justice, reconciliation and healing, testifying to the hope that we live by and

3.1.5 conserve and cultivate creation in the name of God and for the sake of all who live in it. This we do with the deepest motive of glorifying God and in service of the coming of the Kingdom (Rom 12:1-2, Eph 1:10 ff) (Mt 4:23-25, 5:13-16, 9:35-38, 10:7-8, 28:18-20, Lk 6:17-19, 9:1-6, 10:25-37, Jn 20:19-22, Acts 1:8, Heb 3:1, 1 Pet 2:9-10, 1 Pet 3:15). 
3.2 The mission of service and witness occurs where we as the church, in the power of the Holy Spirit, with integrity, in obedience and in following Christ, with compassion and in serving others, in humility but also in boldness, witness about God's love for the world. In the reaching out to all people new borders are continuously crossed and service and witness are not to be separated.

3.3 We are called to service and witness in and from Southern Africa, by

3.3.1 prayerfully, and with others, discerning and obeying God's calling for us in and from this context,

3.3.2 listening with compassion to the voices crying out for deliverance from sin, enslavement, fear, hunger, sickness, pain, violence and injustice - suffering in all its dimensions,

3.3.3 making our prophetic voice heard and being of priestly service in alleviating the need of people in all our communities,

3.3.4 respecting, building and celebrating the good in our rich and diverse heritages, cultures, languages, gifts, contributions and the vast potential in all the people of Southern Africa,

3.3.5 entering into meaningful partnerships with other churches, ecumenical bodies and governmental- and non-governmental institutions,

3.3.6 witnessing to our faith in the Triune God through respectful dialogue with people of other faiths and convictions.

3.4 As the legitimate bearer of this Good News (Gospel), the church of Christ is to be one and to live and work in the likeness of the one triune God, Father, Son and Holy Spirit. "As prisoner for the Lord, then, I urge you to live a life worthy of the calling you have received. Be completely humble and gentle; be patient, bearing with one another in love. Make every effort to keep the Unity of Spirit through the bond of peace. There is one body and one Spirit - just as you were called to one hope when you were called - one Lord, one faith, one baptism; one God and Father of all, who is over all and through all and in all" (Eph 4:1-6). 
Dit is opvallend dat hierdie verklaring missio Dei as vertrekpunt neem, met die klem op 'n Skriftuurlike begronding en gestruktureer aan die hand van die drie Persone van die Triniteit. In die res van die dokument word hierdie verklaring verder ontwikkel.

Hierna het die saak van missionale kerkwees op verskillende maniere op die VGKSA se agenda gekom. Die Algemene Sinode van 2012 het byvoorbeeld kennis geneem van 'n verslag ${ }^{4}$ oor Bediening en Getuienis waarvan die inleiding soos volg lui:

We present the matters we had to deal with during the past recess and those we are currently pursuing to you in the report that follows. We trust you will be blessed by the information and be inspired to keep on being or become involved as co-responsible actors in missional existence and ministry.

Die verslag maak onderskeid tussen "missional existence" en "missional ministry". Dit is duidelik dat die VGKSA die onderskeid tussen "missionaal" en missionêr" verreken, waar die eerste op 'n bepaalde ekklesiologie en selfverstaan dui en die tweede op die aktiwiteite en bediening wat voortvloei vanuit 'n bepaalde selfverstaan. In die taal van die Wêreldraad van Kerke, kan dit verstaan word as die "nature and mission of the church".

In terme van missionale bediening gee die verslag aandag aan die verspreiding van Christelike lektuur, bediening aan mense wat dwelms en alkohol misbruik asook vennootskappe met buitelandse kerke in terme van gemeenskapsprojekte soos watervoorsiening, ekonomiese ontwikkeling van arm gemeenskappe, tuisversorging van siekes en bejaardes, werkskepping en nog meer. Daar is ook in besonder aandag gegee aan die samewerking met die NG Kerk in programme wat te doen het met sosiale geregtigheid.

\subsection{Gereformeerde Kerke in Suid-Afrika (GKSA)}

Tydens die Algemene Sinode van die Gereformeerde Kerke in Suid-Afrika wat in 2015 in Potchefstroom plaasgevind het, is breedvoerige aandag gegee aan 'n "omkeerstrategie", veral in die lig van dalende lidmaatgetalle.

4 URCSA General Synod Core Ministry for Service and Witness (CMSW): Report to the URCSA General Synod in session on 1-7 October 2012 at Okahandja, Namibia. 
Deel van die gesprek het gehandel oor wat onder "missionale ekklesiologie" verstaan word.

In die rapport (GKSA 2015) wat voor die sinode gedien het, word die volgende daaroor gesê:

\subsubsection{Die begrip missio Dei}

(1) Die uitdrukking missio Dei is nie net 'n begrip van akademiese belang nie. God is 'n God wat stuur en op dinamiese wyse in beheer bly van hierdie wêreld. (Die Deputate verwys in hierdie verband na die artikel van prof G Breed met die titel, 'n Kritiese blik op missio Dei in die lig van Efesiërs wat ook op die CD verskyn.)

(2) God eis van sy kerk (kuriake, hulle wat aan die Here behoort) deelname aan hierdie sending (missio Dei). Hoe? Deur om te gee en op te pas en uit te reik na ongelowiges en buite kerklikes.

(3) Die bedoeling met die offer van die kruis van Jesus Christus word deur Homself in missionale- en wêreldperspektief gebring.

(4) 'n Missionale kerk maak erns daarmee om te gaan om getuies te wees tot aan die einde van die aarde en om 'n verlange te hê dat mense uit al die nasies die knie voor Jesus Christus sal buig.

(5) Om missionaal te leef, is 'n intensionele bestaanswyse in die opsig dat God se Woord die trekkende krag is.

Die kritiese vraag wat gestel moet word, is in watter mate die verskillende kerke in die GKSA identifiseer met hierdie "omkeerstrategie" gegrond in die missio Dei en missionale ekklesiologie. 'n Verdere vraag is hoe 'n missionale ekklesiologie versoenbaar of aanvullend kan staan tot 'n ekklesiologie soos geartikuleer in die Dordtse kerkorde. As mens die noue verband tussen ekklesiologie en kerkorde in gedagte hou, kan 'n missionale ekklesiologie juis bepaalde kortsluitings veroorsaak binne 'n presbiteriaalsinodale kerkbegrip en kerkorde.

\section{Ten slotte: Missionale ekklesiologie in die toekoms?}

Uit hierdie oorsig is duidelik dat missio Dei en missionale kerkwees na 1990 sleutelbegrippe was in die ontwikkeling van 'n nuwe benadering tot 
sending en kerkwees ook hier in Suid-Afrika. Die fokus het verskuif na die plaaslike gemeente en die wyse waarop die gemeente elke dag voor die aangesig van God (coram Deo) leef en in die wêreld teenwoordig is. Daar is min twyfel dat missio Dei en missionale kerkwees tans die denke en praktyk van gereformeerde kerke oorheers.

Wat sou die kontoere van 'n missionale ekklesiologie wees, waarmee kerke in die gereformeerde tradisie die toekoms kan ingaan? $\mathrm{Na}$ die Tweede Wêreldoorlog het ekklesiologie, om verskeie redes, heelwat aandag gekry. 'n Groot aantal monografieë en naslaanwerke het die afgelopetien jaar verskyn, byvoorbeeld die Routledge Companion to the Christian Church (Mannion \& Mudge 2010) en die Oxford Handbook of Ecclesiology (Avis 2018). VeliMatti Kärkkäinen (2002:7) noem dit 'n ekklesiologiese renaissance (sien ook Dreyer 2016:25). Ekklesiologie is 'n teologiese dissipline wat die kerk bestudeer. Die wese, roeping, geskiedenis en praktyk van die kerk staan sentraal. Missionale ekklesiologie plaas die fokus op die apostolisiteit van die kerk, maar dit het ook met die wese, roeping, geskiedenis en praktyk van die kerk te doen.

Missionale ekklesiologie is dus een van die onderafdelings van ekklesiologie (Avis 2018: 13). Avis toon aan dat daar 'n "intimate relationship" tussen ekklesiologie en missiologie bestaan. Hy gaan selfs sover as om te argumenteer dat missiologie 'n onderafdeling van ekklesiologie is, omdat die kerk die opdrag het om sendingwerk te doen. Sending hoort tot die wese van die kerk, daarom hoort missiologie en ekklesiologie bymekaar. Avis beklemtoon dat dit voortvloei uit die missio Dei. In die verband verwys hy na die invloed van David Bosch in die ontwikkeling van missiologie, ekklesiologie en wat Avis 'n "missionary ecclesiology" noem (Avis 2018:13). Ook Collins, in sy hoofstuk in die Routledge Companion, toon aan hoe die missio Dei-denke vanaf Barth (sien Barth 1932 [1957]) en Hartenstein na Willingen en daarna wêreldwyd versprei het, veral onder invloed van David Bosch (Collins 2010:629). Ekklesiologie en missiologie is onafskeidbaar verbind, daarom is dit vanselfsprekend dat iets soos "missionale ekklesiologie" sou ontwikkel.

Die term "missionale ekklesiologie" het sy oorsprong by Darrell Guder (1939 -), 'n teoloog vroeër verbonde aan die Princeton Seminarie in die VSA. Guder het sy $\mathrm{PhD}$ aan die Universiteit van Hamburg (Duitsland) voltooi. 
Sy navorsing fokus op missionale kerkwees in 'n post-Christelike era. Hy is ook bekend vir sy vertalings van Duitse teologie na Engels, insluitend die werke van Otto Weber, Eberhard Jüngel en Karl Barth. Dit is opmerklik dat hy (soos Bosch) deur die teologie van Karl Barth beïnvloed is. Guder het in 1998 'n invloedryke boek gepubliseer, te wete Missional Church: A vision for the sending of the church in North America (Guder 1998). Die titel spreek vanself: Dit gaan om 'n missionale ekklesiologie. Die woord "missionaal” is taalkundig en inhoudelik anders as "missionêr". Eersgenoemde het te doen met die wese van die kerk, laasgenoemde gaan om die handelinge van die kerk. Missionale kerkwees gaan om meer as 'n sendingprojek, dit gaan om 'n eksistensiële bestaanswyse, 'n bepaalde selfverstaan en identiteit.

In 'n volgende publikasie (Guder 2000) argumenteer Guder vir fundamentele kerkhervorming. Hy gebruik die slagspreuk ecclesia semper reformanda as vertrekpunt en toon aan dat die kerk moet transformeer tot 'n missionale kerk. Dit is opvallend dat Guder nogmaals teruggryp na die teologie van Barth, soos blyk uit hoofstuk 6 van The Continuing Conversion of the Church (Guder 2000:120-141). Wanneer Guder in Deel III uitspel wat belangrik is in die hervorming van die kerk tot missionale kerkwees, begin hy deur te beklemtoon dat dit alles met die plaaslike gemeente begin (Guder 2000:145). Saam met die Wêreldraad van Kerke kom Guder tot die gevolgtrekking: "A vital instrument for the fulfilment of the missionary vocation of the Church is the local congregation" (Guder 2000:145).

Dit is hierdie benadering wat veral na 2000 al groter invloed op die Afrikaanse kerke uitgeoefen het. In hierdie verband moet daar gewys word op die belangrike bydrae van Nelus Niemandt om missionale kerkwees in die praktyk en ook in akademiese publikasies te bevorder (sien as voorbeeld Niemandt 2012).

Ten slotte word volstaan met die kenmerke van 'n missionale ekklesiologie, soos deur Niemandt (2012:2-8) geformuleer. Niemandt sistematiseer sy verstaan van missionale kerkwees onder die opskrifte hieronder. Ruimte ontbreek om op elkeen van hierdie onderafdelings kommentaar te lewer, maar die opskrifte spreek vanself.

- Participation in the life of the Trinity

- Joining in with the Spirit

- Ecclesiology follows mission 
- Incarnational - or universal and contextual

- Relational

- The Kingdom of God

- Discernment as the first act of mission

- Creativity

- Local Community

- Ethics and mission

Dit is ten slotte duidelik dat missionale kerkwees ingrypende vrae ook aan die Afrikaanse gereformeerde kerke en elke plaaslike gemeente stel: naamlik hoe die kerk en gemeentes onderskeidend, inkarnerend, relasioneel, kreatief en met integriteit in die kragveld van die Gees kan leef, met die doel om in elke gegewe konteks diensbaar te wees aan die koninkryk van God. Wat egter ook verder duidelik is, is dat die nadenke oor missionale ekklesiologie baie skerp in die fokus van hierdie kerke staan.

\section{Geraadpleegde bronne}

Agaard, J. 1965. Some main trends in modern protestant missiology.

Studia Theologica - Nordic Journal of Theology, 19:1-2, pp. 238-259.

Anderson, G.H. 2006. In Memoriam David J Bosch (1929-1992). In

Transforming Mission. Maryknoll NY: Orbis Books.

Avis, P. (red.). 2018, The Oxford Handbook of Ecclesiology. Oxford: Oxford University Press.

Barth, K. [1932] 1957. Die Theologie und die Mission in der Gegenwart.

In Theologischen Fragen und antworten Vol. 3. Zollikon-Zürich

Evangelischer Verlag. pp. 100-126

Buys, P.J. 2020. “The roots of missio Dei in the Reformation, and its implications for theological education”. In die Skriflig, 54(2):a2585. https://doi.org/10.4102/ids.v54i2.2585. 
Benadé, C.R. 2019. A church after God"s heart: Discerning a missional ecclesiology for the Dutch Reformed Church in South Africa. PhD Thesis in the Department of Science of Religion and Missiology, University of Pretoria.

Benadé, C.R. \& Niemandt, C.J.P. 2019. Mission awakening in the Dutch Reformed Church: The possibility of a fifth wave? HTS Teologiese Studies/ Theological Studies, 75(4):a5321. https://oi.org/10.4102/hts. v75i4.5321

Bevans, S.B. and Schroeder, R.P. 2005. Missiology after Bosch:

Reverencing a classic by moving beyond. International Bulletin of Missionary Research, 29(2):69-72.

Bosch, D.J. [1991] 2006. Transforming mission: Paradigm shifts in Theology of Mission, 22nd Edition. New York: Orbis Books.

Collins, P.M. 2010. Ecclesiology and World Mission / Missio Dei. In G. Mannion \& L.S. Mudge (ed.). The Routledge Companion to the Christian Church. Routledge, New York. pp. 623-636.

Dreyer, W.A. 2011. 'n Multidissiplinêre benadering tot Praktiese Ekklesiologie. HTS Teologies Studies/ Theological Studies, 67(2), Art. \#1088, 9 pages. https://dx.doi.org/10.4102/hts.v67i2.1088

Dreyer, W.A. 2013. Missional ecclesiology as basis for a new church order: A case study. HTS Teologiese Studies/Theological Studies, 69(1), Art. \#1368, 5 pages. https://dx.doi.org/10.4102/hts.v69i1.1368

Dreyer, W.A. 2016. Empiriese perspektief op kerkwees, in "Praktiese ekklesiologie - Kerkwees in die 21ste eeu". HTS Teologiese Studies/ Theological Studies, suppl. 10, 72(5):a4379. https://dx.doi.org/10.4102/ hts.v72i5.4379

Dreyer, W.A. 2017. Karl Barth's Römerbrief: A Turning Point in Protestant Theology. Studia Historiae Ecclesiasticae, 43(3). https://upjournals. co.za/index.php/SHE/index

Du Plessis, J. 1911 [1965]. Christian Missions in South Africa. Cape Town: C.Struik. 
Engelsviken, T. 2003 Missio Dei: The understanding and misunderstanding of a theological concept in European churches and missiology. International Review of Mission, 92(367). pp. 481-497.

Flett, J.G. 2010. The witness of God. The Trinity, Missio Dei, Karl Barth and the Nature of the Christian Community. Grand Rapids: William B. Eerdmans Publishing Company.

Flett, J.G. 2014. A Theology of Missio Dei. Theology in Scotland, 21(1):6978.

Gereformeerde Kerke in Suid-Afrika 2015. Handelinge van die Algemene Sinode 2015. Potchefstroom: Kerkargief. [Aanlyn]. Beskikbaar: https:// www.gksa.org.za/sinode2015.htm

Guder, D. (ed.) 1998. Missional church: A vision for the sending of the church in North Americ. Grand Rapids: Eerdmans.

Guder, D. 2000. The continuing conversion of the church. Grand Rapids: Eerdmans.

Hartenstein, K. 1928. Was hat die Theologie Karl Barth's der Mission zu sagen? Munich: Chr. Kaiser Verlag.

Hartenstein, K. 1933. Die Mission als theologisches Problem: Beitrage zum grundsatzlichen Verstandnis der Mission. Berlin: Furche.

Hartenstein, K. 1939. Die trinitarische Verkündigung in der Welt der Religionen. In Die Deutsche Evangelische Heidenmission Jahrbuch. Hamburg: Selbstverlag der Missions Konferenz.

Joseph, P.V. 2019. An Indian Trinitarian Theology of Missio Dei: Insights from St. Augustine and Brahmabandhab Upadhyay, American Society of Missiology Monograph Series 39. Eugene, OR: Pickwick Publications.

Kärkkäinen, V-M. 2002. An Introduction to Ecclesiology. Downers Grove: InterVarsity Press.

Kritzinger, J.J. 2011. Die einde van sending. Fases in die Sendingbedryf. Acta Theologica, 31(2):111-134. doi: http://dx.doi.org/10.4314/actat. v31i2.6 
Nederduitsch Hervormde Kerk van Afrika. 2016a. Besluitebundel van die 71ste Algemene Kerkvergadering. Pretoria: Kerkargief.

Nederduitsch Hervormde Kerk van Afrika. 2016b. Kerkorde van die Nederduitsch Hervormde Kerk van Afrika. Pretoria: Kerkargief. [Aanlyn]. Beskikbaar: https://nhka.org/amptelik/\#argief

Niemandt, C.J.P. 2012 Trends in missional ecclesiology. HTS Teologiese Studies/Theological Studies, 68(1), Art. \#1198. https://dx.doi. org/10.4102/hts.v68i1.1198

Richebächer, W. 2003. Missio Dei: The basis for mission or a wrong path? International Review of Mission, 92(367):588-605.

Saayman, W. 2003. 'n Nuwe horison - verkenning ten opsigte van 'n sosiale geskiedenis van die Nederduitse Gereformeerde Sending. Verbum et Ecclesia, 24(1):194-212). doi:10.4102/ve.v24i1.321.

Saayman, W. 2007. Being missionary, being human. Pietermaritzburg: Cluster.

Vicedom, G.F. 1958. Missio Dei: Einführung in eine Theologie der Mission. München: Christian Kaiser Verlag.

Vicedom, G.F. 1975. Actio Dei: Mission und Reich Gottes. München: Christian Kaiser Verlag. 
